\title{
Spontaneous intracranial hypotension with camptocormia
}

回

Supplemental data at Neurology.org
Camptocormia is defined as an abnormal flexion of the thoracolumbar spine that appears while standing or walking. It is associated with several clinical situations such as parkinsonism, dystonia, and neuromuscular disorders. ${ }^{1,2}$ We present the case of a 33-year-old man who had marked camptocormia with acute onset (video on the Neurology ${ }^{\circledR}$ Web site at Neurology.org). The patient also had a 2-day history of severe orthostatic headache. Through brain MRI and CSF examination, he was diagnosed with spontaneous intracranial hypotension. After an autologous blood patch, postural headache and camptocormia were dramatically improved. Camptocormia in this patient may have occurred to compensate for severe orthostatic headache.

In-Seok Park, MD, Joong-Seok Kim, MD, PhD

From the Department of Neurology, College of Medicine, The Catholic University of Korea, Seoul.

Author contributions: I.S. Park: drafting the first manuscript, analysis or interpretation of data. J.-S. Kim: drafting/revising the manuscript, study concept or design, analysis or interpretation of data.

Study funding: No targeted funding reported.

Disclosure: The authors report no disclosures relevant to the manuscript. Go to Neurology.org for full disclosures.

Correspondence to Dr. Kim: neuronet@catholic.ac.kr

1. Djaldetti R, Mosberg-Galili R, Sroka H, Merims D, Melamed E. Camptocormia (bent spine) in patients with Parkinson's disease: characterization and possible pathogenesis of an unusual phenomenon. Mov Disord 1999;14:443-447.

2. Umapathi T, Chaudhry V, Cornblath D, Drachman D, Griffin J, Kuncl R. Head drop and camptocormia. J Neurol Neurosurg Psychiatry 2002;73:1-7. 


\title{
Neurology
}

\author{
Spontaneous intracranial hypotension with camptocormia \\ In-Seok Park and Joong-Seok Kim \\ Neurology 2014;82;1751 \\ DOI 10.1212/WNL.0000000000000411
}

This information is current as of May 12, 2014

\section{Updated Information \& Services \\ Supplementary Material \\ References \\ Subspecialty Collections}

Permissions \& Licensing

Reprints including high resolution figures, can be found at: http://n.neurology.org/content/82/19/1751.full

Supplementary material can be found at: http://n.neurology.org/content/suppl/2014/05/11/82.19.1751.DC1

This article cites 2 articles, 1 of which you can access for free at: http://n.neurology.org/content/82/19/1751.full\#ref-list-1

This article, along with others on similar topics, appears in the following collection(s):

\section{All Movement Disorders}

http://n.neurology.org/cgi/collection/all_movement_disorders

\section{Dystonia}

http://n.neurology.org/cgi/collection/dystonia

Low pressure syndrome

http://n.neurology.org/cgi/collection/low_pressure_syndrome

Information about reproducing this article in parts (figures,tables) or in its entirety can be found online at:

http://www.neurology.org/about/about_the_journal\#permissions

Information about ordering reprints can be found online: http://n.neurology.org/subscribers/advertise

Neurology ${ }^{\circledR}$ is the official journal of the American Academy of Neurology. Published continuously since 1951, it is now a weekly with 48 issues per year. Copyright () 2014 American Academy of Neurology. All rights reserved. Print ISSN: 0028-3878. Online ISSN: 1526-632X.

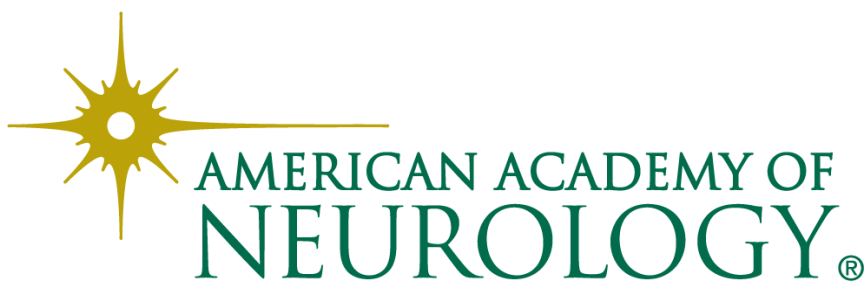

